DOE/MC/93014-96/C0703

$$
\text { CONF-960805--6 }
$$

High Efficiency Carbonate Fuel Cell/Turbine Hybrid Power Cycle

Author:

George Steinfeld

Hans C. Maru

Robert A. Sanderson

\title{
Contractor:
}

Energy Research Corporation

3 Great Pasture Road

Danbury, CT 06813

\section{Contract Number:}

CRADA 93-014

\section{Conference Title:}

IECEC '96

Conference Location:

Washington, DC

\section{Conference Dates:}

August 11-16, 1996

\section{Conference Sponsor:}

Institute of Electrical and Electronics Engineers (IEEE), American Institute of Chemical Engineers (AIChE), Society Aeronautical Engineers (SAE), American Institute of Aeronautics and Astronautics (AIAA), and American Society of Mechanical Engineers (ASME)

Contracting Officer Representative (COR): Fred Sudhoff 


\section{DISCLAIMER}

Portions of this document may be illegible in electronic image products. Images are produced from the best available original document. 


\section{DISCLAIMER}

This report was prepared as an account of work sponsored by an agency of the United States Government. Neither the United States Government nor any agency thereof, nor any of their employees, makes any warranty, express or implied, or assumes any legal liability or responsibility for the accuracy, completeness, or usefulness of any information, apparatus, product, or process disclosed, or represents that its use would not infringe privately owned rights. Reference herein to any specific commercial product, process, or service by trade name, trademark, manufacturer, or otherwise does not necessarily constitute or imply its endorsement, recommendation, or favoring by the United States Government or any agency thereof. The views and opinions of authors expressed herein do not necessarily state or reflect those of the United States Government or any agency thereof. 
Page 2 of 2 (1332.15)

\section{Conference Sponsors:}

Institute of Electrical and Electronics Engineers (IEEE), American Institute of Chemical Engineers (AIChE), Society Aeronautical Engineers (SAE), American Institute of Aeronautics and Astronautics (AIAA), and American Society of Mechanical Engineers (ASME)

\section{RECEIVED \\ JUL 291996 \\ OSTI}




\section{DISCLAIMER}

This report was prepared as an account of work sponsored by an agency of the United States Government. Neither the United States Government nor any agency thereof, nor any of their employees, makes any warranty, express or implied, or assumes any legal liability or responsibility for the accuracy, completeness, or usefulness of any information, apparatus, product, or process disclosed, or represents that its use would not infringe privately owned rights. Reference herein to any specific commercial product, process, or service by trade name, trademark, manufacturer, or otherwise does not necessarily constitute or imply its endorsement, recommendation, or favoring by the United States Government or any agency thereof. The views and opinions of authors expressed herein do not necessarily state or reflect those of the United States Government or any agency thereof.

Available to the public from the National Technical Information Service, U.S. Department of Commerce, 5285 Port Royal Road, Springfield, VA 22161; phone orders accepted at (703) 487-4650. 


\title{
HIGH EFFICIENCY CARBONATE FUEL CELLUTURBINE HYBRID POWER CYCLE
}

\author{
George Steinfeld and Hans C. Maru \\ Energy Research Corp. \\ 3 Great Pasture Road Danbury, CT 06813 \\ Tel. 203-792-1460 Fax 203-798-2945 \\ Robert A. Sanderson P.E. \\ Robert Sanderson \& Associates \\ 115 Apple Hill \\ Wethersfield, CT 06019 \\ Tel. 860-563-9823 Fax 860-721-6459
}

\section{ABSTRACT}

Energy Research Corporation conducted studies of hybrid power cycles in cooperation with the U.S. Department of Energy, Morgantown Energy Technology Center (METC) to identify a high efficiency, economically competitive system. A hybrid power cycle which generates power at an LHV efficiency in excess of $70 \%$ was identified that includes an atmospheric pressure direct carbonate fuel cell, a gas turbine and a steam cycle. In the hybrid power cycle, natural gas fuel is mixed with recycled fuel cell anode exhaust, providing water for reforming fuel. The mixed gas then flows to a direct carbonate fuel cell which generates about $70 \%$ of the power. The portion of the fuel cell anode exhaust which is not recycled is burned and heat is transferred through a heat exchanger to the compressed air from a gas turbine. The heated compressed air is then heated further in the gas turbine burner and expands through the turbine generating $15 \%$ of the power. Half the exhaust from the turbine provides air for the anode exhaust bumer. All of the turbine exhaust eventually flows through the fuel cell cathodes providing the $\mathrm{O}_{2}$ and $\mathrm{CO}_{2}$ needed in the electrochemical reaction. Exhaust from the fuel cell cathodes flows to a steam system that includes a heat recovery steam generator and staged steam turbine which generates $15 \%$ of the hybrid cycle power.

Simulation studies of a $200 \mathrm{MW}$ plant with a hybrid power cycle showed an LHV efficiency of $72.6 \%$. The hybrid cycle power output and efficiency are relatively insensitive to ambient temperature,compared to a gas turbine combined cycle. The $\mathrm{NO}_{\mathrm{x}}$ emissions from the hybrid power cycle are $75 \%$ lower than the level from a combined cycle. The estimated cost of electricity for a 200 $\mathrm{MW}$ with a hybrid power cycle is $46 \mathrm{mills} / \mathrm{kWh}$, which is competitive with a combined cycle for installations where fuel cost is above \$5.8/MMBTU. A key technology requirement in the hybrid power cycle is the heat exchanger which transfers heat to the compressed air from a gas turbine. In the $200 \mathrm{MW}$ plant studies, a heat exchanger that operates at $1094^{\circ} \mathrm{C}$ was assumed to take advantage of high temperature heat exchanger technology currently under development by METC for coal gasifiers.

Studies of a near term high efficiency direct carbonate fuel cell/turbine hybrid power cycle have also been completed and are the subject of a paper to be presented at the Fuel Cell Seminar in Orlando, Florida in November 1996 . These later studies were focused on a $20 \mathrm{MW}$ hybrid power cycle for near term application.

\section{INTRODUCTION}

Direct carbonate fuel cells developed by Energy Research Corporation (ERC) generate power at an efficiency approaching $60 \%$. A $2 \mathrm{MW}$ power plant demonstration of this technology is presently under way at an installation in the city of Santa Clara in California. A $2.85 \mathrm{MW}$ commercial configuration, shown in Figure 1, is presently being developed. The complete plant includes the carbonate fuel cell modules, power conditioning equipment, a heat recovery unit and supporting instrument air and water treatment systems. The emission levels for this $2.85 \mathrm{MW}$ plant are orders of magnitude below existing or proposed standards. The $\mathbf{3 0}$ year levelized cost of electricity, without inflation, is projected to be under 52 mills/kWh assuming a capital cost for the carbonate fuel cell system of $\$ 1000 / \mathrm{kW}$.

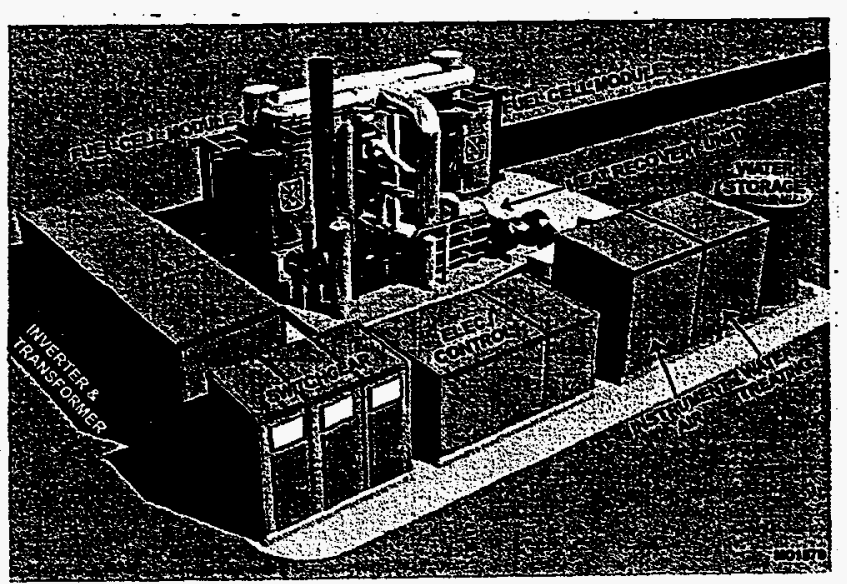

FIGURE 1. 2.85 MW POWER PLANT:

The Basic Direct Fuel Cell Technology for 200 MW Hybrid Cycle

ERC conducted studies of hybrid power cycles in cooperation with the U.S. Department of Energy, Morgantown Energy Technology Center (METC) to identify a higher efficiency, economically competitive system. A hybrid power cycle which integrates fuel cell and turbine technology generating power at an LHV efficiency in excess of $70 \%$ was identified. This paper describes the direct carbonate atmospheric pressure fuel cell/turbine hybrid power cycle and presents the results of studies on the application of this new cycle to a $200 \mathrm{MW}$ power plant. 


\section{HYBRID POWER CYCLE DESCRIPTION}

The direct carbonate atmospheric pressure fuel cell/turbine hybrid power cycle is shown in Figure 2. The system includes a direct carbonate fuel cell, a gas turbine, and a steam cycle. Natural gas flows to the fiel cell and the gas turbine. Air flows to the gas turbine, and exhaust from the gas turbine flows to the fuel cell. Fuel exhaust from the fuel cell is oxidized providing heat to the gas turbine. Exhaust from the fuel cell flows to the steam cycle.

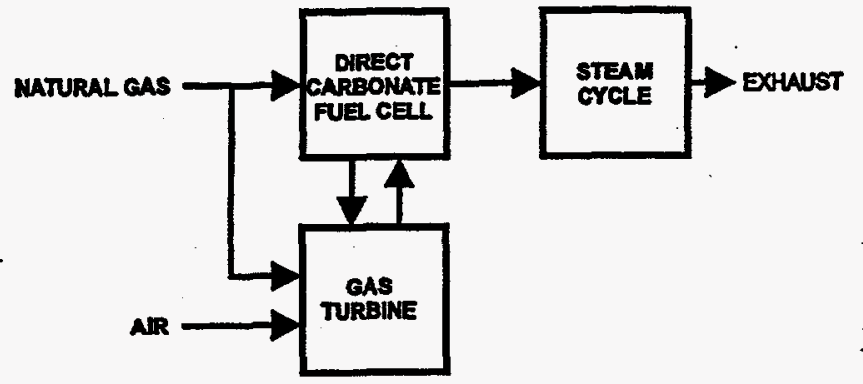

morew

\section{FIGURE 2. MAJOR ELEMENTS OF HYBRID POWER CYCLE:}

An Integrated System to Maximize Electrical Efficiency

In the direct carbonate fuel cell system water vapor is mixed with the natural gas and is intermally steam reformed producing $\mathrm{CO}$ and $\mathrm{H}_{2}$ as follows:

$$
\mathrm{CH}_{4}+1.5 \mathrm{H}_{2} \mathrm{O}+\mathrm{Heat} \rightarrow \mathrm{CO}+3 \mathrm{H}_{2}+0.5 \mathrm{H}_{2} \mathrm{O} \text { Reform }
$$

$$
\begin{array}{lr}
\mathrm{CO}+\mathrm{H}_{2} \mathrm{O} \rightarrow \mathrm{CO}_{2}+\mathrm{H}_{2} & \text { Shift } \\
\mathrm{H}_{2}+\mathrm{CO}_{3}{ }^{-} \rightarrow \mathrm{H}_{2} \mathrm{O}+\mathrm{CO}_{2}+2 e^{-} & \text {Anode Reaction } \\
\mathrm{O}_{2}+2 \mathrm{CO}_{2}+2 \mathrm{e}^{-} \rightarrow 2 \mathrm{CO}_{3}= & \text { Cathode Reaction }
\end{array}
$$

The $\mathrm{CO}$ is shifted with water vapor produced at the cell anodes providing additional $\mathrm{H}_{2}$, as shown in Reaction 2. The $\mathrm{H}_{2}$ reacts electrochemically (with the carbonate ion) in the fuel cell anode. In the cathode, $\mathrm{CO}_{2}$ reacts with oxygen from air producing a carbonate ion (Reaction 4) which migrates to the anode electrode through the electrolyte.

$$
\mathrm{CH}_{4}+2 \mathrm{O}_{2} \rightarrow \mathrm{CO}_{2}+2 \mathrm{H}_{2} \mathrm{O}+\text { Electricity }+ \text { Heat } \begin{array}{r}
\text { Overall } \\
\text { Reaction }
\end{array}
$$

The overall Reaction 5 results in electrochemical oxidation of the fuel producing $\mathrm{CO}_{2}$ and $\mathrm{H}_{2} \mathrm{O}$. Heat generated in the fuel cells provides more than enough heat for the reforming process (Reaction 1) which occurs within the fuel cell stack.

\section{MW PLANT SYSTEM}

A system schematic for a $200 \mathrm{MW}$ plant with the hybrid power cycle is shown in Figure 3. In this system, about $95 \%$ of the methane fuel flows to near atmospheric pressure direct internal reforming carbonate fuel cells. The methane is internally reformed to $\mathrm{H}_{2}$ and $\mathrm{CO}$. The water required for reforming is recycled from the fuel cell anode exit. About $80 \%$ of the $\mathrm{H}_{2}$ and $\mathrm{CO}$ is consumed in the cell anodes generating $\mathrm{DC}$ power. The unreacted $\mathrm{H}_{2}$ and $\mathrm{CO}$ flows to a bumer which operates at $1094^{\circ} \mathrm{C}$.

Five percent of the methane fuel is compressed and flows to the gas turbine combustor. The gas turbine compressor delivers air at 360 psia to a high temperature heat exchanger which heats the air to $982^{\circ} \mathrm{C}$. The heated air then flows to the gas turbine combustor where it is heated further to $1094^{\circ} \mathrm{C}$ before flowing through the turbine. Turbine exhaust containing $\mathrm{O}_{2}$ and $\mathrm{CO}_{2}$ is split with $50 \%$ of the stream flowing to the fuel cell cathodes and $50 \%$ flowing to the anode exhaust bumer. Exhaust from the cathode recycle burner heats the compressed air in the high temperature heat exchanger before joining the stream to the fuel cell cathodes. Exhaust from the cathodes at $677^{\circ} \mathrm{C}$ flows to the steam bottoming system. The steam bottoming system includes a Heat Recovery Steam Generator (HRSG) high, intermediate and low pressure steam turbines, a condenser and condensate pump. The HRSG includes a reheater, superheater, high pressure boiler, economizer, and a low pressure boiler. The system also includes a condensate reheater, deaerator, boiler feed pump and exhaust blower not shown on the simplified schematic.

This system is self-sufficient in its water management. There is no net requirement for process water other than for make-up of blowdown from the boilers. Exhaust from the system is at $67^{\circ} \mathrm{C}$, with a dew point of about $54^{\circ} \mathrm{C}$.

In the system described above, water is provided for the reforming process by anode recycle in which a portion of the fuel cell anode exhaust is recycled back to the inlet of the process. An alternative way is to provide the water vapor for the reforming process in the fuel cell stacks from the steam bottoming cycle. Both of these options were explored in studies of the hybrid power cycle for a 200 MW power plant.

\section{MW HYBRID POWER CYCLE PLANT PERFORMANCE}

The performance of the $200 \mathrm{MW}$ plant with a hybrid power cycle was analyzed using a CHEMCAD ${ }^{1}$ system model with an ERC developed fuel cell model. The results are shown in Table 1 for a system in which water vapor for the reforming is by anode recycle and for a system in which the water comes as steam from the steam system.

In the hybrid power cycle, about $70 \%$ of the power is produced by the fuel cell system, about $15 \%$ comes from a generator driven by the gas turbine, and the remaining $15 \%$ comes from generators driven by the three steam turbines. There is about $5 \%$ parasitic power for pumps and blowers in the system.

\section{PERFORMANCE SENSITIVITY TO SITE CONDITIONS}

In the performance studies of the hybrid power cycle presented above, the assumed site conditions are sea level and $15^{\circ} \mathrm{C}$ ambient air. The effect of ambient temperature above $15^{\circ} \mathrm{C}$ and elevations above sea level was also investigated. The results indicate that the hybrid power cycle system is relatively insensitive to changes in ambient temperature or elevation. The effect of ambient temperatures at $35^{\circ} \mathrm{C}$ and $49^{\circ} \mathrm{C}$ on the performance of the hybrid power cycle system with anode recycle is shown in Table 2 . An ambient temperature of $49^{\circ} \mathrm{C}$ results in only $4.2 \%$ reduction in the net power generation. 




FIGURE 3. SYSTEM SCHEMATIC OF HYBRID POWER CYCLE:

Important State Points are Indicated

TABLE 1.

200 MW HYBRID POWER CYCLE PERFORMANCE: Over $70 \%$ Efficiency is Projected

\begin{tabular}{|l|c|c|}
\hline & $\begin{array}{c}\text { WATER } \\
\text { FROM } \\
\text { STEAM } \\
\text { SYSTEM }\end{array}$ & $\begin{array}{c}\text { WATER } \\
\text { BY } \\
\text { ANODE } \\
\text { RECYCLE }\end{array}$ \\
\hline POWER GENERATION & & \\
\hline MW & 28.9 & 27.1 \\
\hline GAS TURBINE & 159.4 & 157.6 \\
\hline FUEL CELL & 26.6 & 32.8 \\
\hline STEAM TURBINE & -11.6 & -11.1 \\
\hline PARASITIC POWER & 203.3 & 206.4 \\
\hline TOTAL & & \\
\hline NET AC LHV EFFICIENCY & & 61.7 \\
\hline \% & 58 & 55.1 \\
\hline FUEL CELL & 62 & 34.1 \\
\hline FUEL CELL + GAS & 32.5 & 72.6 \\
\hline TURBINE & 70.2 & \\
\hline STEAM SYSTEM & & \\
\hline OVERALL & & \\
\hline
\end{tabular}

As ambient temperature goes up from $15^{\circ} \mathrm{C}$ to $35^{\circ} \mathrm{C}$ and to $49^{\circ} \mathrm{C}$, the fuel cells, which produce $70 \%$ of the power, have a relatively constant output. There is a $7-11 \%$ increase in the gas turbine compressor work and gas turbine net output is reduced $14-22 \%$. More fuel cell waste heat is transferred in the high temperature heat exchanger and the gas turbine raw fuel flow is reduced $35-56 \%$. A higher fraction of the gas turbine exhaust flows directly to the fuel cell for cooling and the exhaust recycle blower has 4-13\% less parasitic loss. The net result is 3-4\% less power output and 2-3 \% less fuel flow. The result is a reduction in efficiency of only $1-1.3 \%$, as shown in Table 2.

TABLE 2.

EFFECT OF AMBIENT TEMPERATURE ON HYBRID POWER CYCLE PERFORMANCE:

The Hybrid Cycle is Insensitive to Ambient Conditions

\begin{tabular}{|l|c|c|c|}
\hline AMBIENT TEMP., ${ }^{\circ} \mathrm{C}$ & 15 & 35 & 49 \\
\hline NET POWER, MW & 206.4 & 200.6 & 197.8 \\
\hline EFFICIENCY, $\%$ & 72.6 & 72.0 & 71.7 \\
\hline
\end{tabular}

A comparison of the hybrid power cycle performance at temperatures above $15^{\circ} \mathrm{C}$ against a typical gas turbine combined cycle ${ }^{3,6}$ is shown in Figure 4. A combined cycle is expected to have a $15 \%$ reduction in power rating at $49^{\circ} \mathrm{C}$, compared to only $4 \%$ reduction in power rating with a hybrid power cycle.

The effect of elevation on the performance of the hybrid power cycle was also invertigated and showed that the performance is relatively insensitive to site elevation with power rating reduction of only $2.1 \%$ between sea level and 5,000 foot site elevation.

\section{MW HYBRID POWER CYCLE PLANT EMISSIONS}

Although the hybrid power cycle has about $70 \%$ of its power generated by the fuel cells, there is an anode exhaust combustor and a gas turbine burner which can generate nitrous oxides, $\mathrm{NO}_{\mathrm{x}} \mathrm{A}$ comparison of the $\mathrm{NO}_{x}$ between a hybrid power cycle and a gas 


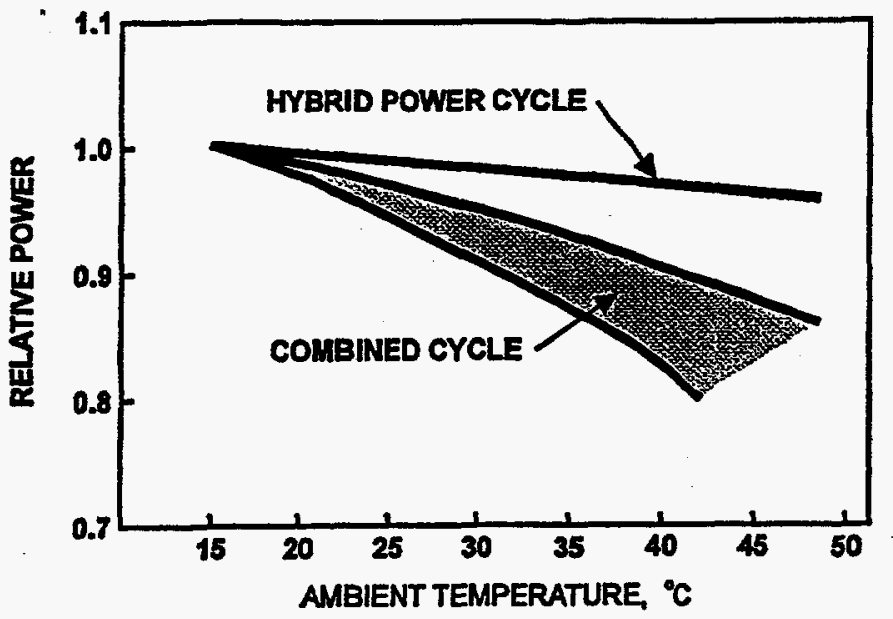

Morsssh

\section{FIGURE 4. PERFORMANCE SENSITIVITY TO SITE TEMPERATURE:}

Hybrid Cycle Has Significant Advantage Over Combined Cycle

turbine combined cycle was made on the basis of equilibrium levels predicted from the combustors in the two systems at their respective operating conditions. The results showed that the hybrid power cycle is expected to generate $75 \%$ less $\mathrm{NO}_{x}$ than a gas turbine combined cycle.

The emission of sulfur dioxide, $\mathrm{SO}_{x}$ is expected to be only about $1 \%$ of the level from a gas turbine combined cycle because the fuel is desulfurized as a first step in the process (not shown on the simplified system schematic Figure 3). The contribution of carbon dioxide, $\mathrm{CO}_{2}$, to the atmosphere is expected to be about $25 \%$ lower than a gas turbine combined cycle due to the higher efficiency.

\section{MW HYBRID POWER CYCLE PLANT COST OF ELECTRICITY}

The 30 year levelized cost of electricity for the $200 \mathrm{MW}$ plant with a hybrid power cycle was estimated at 45.8 mills/kWh, without inflation, using methods recommended in EPRI TAG ${ }^{3}$. This includes a levelized plant cost of 12.5 mills $/ \mathrm{kWh}$, operating and maintenance (O\&M) cost of 11.9 mills/kWh, and levelized fuel cost of 21.4 mills/kWh.

The 30 year levelized plant cost is based on a capital cost of 974 $\$ / \mathrm{kW}$ in 1995 dollars. This overall plant capital cost includes 1000 $\$ / k W$ for the fuel cell system based on projections by ERC. The capital cost for the gas turbine was estimated at $450 \mathrm{~S} / \mathrm{kW}^{4}$, and the steam system at $620 \mathrm{~S} / \mathrm{kW}$. The cost of the system high temperature heat exchanger was estimated at $53 \mathrm{~S} / \mathrm{kW}^{\text {? }}$.

The O\&M cost includes the fuel cell system estimated at $\mathbf{9 . 2}$ mills $k W h$ including five year fuel cell stack replacement. The O\&M costs for the gas turbine and steam system are 1.7 mills/kWh and 0.9 mills $/ \mathrm{kWh}$, respectively.

The levelized fuel cost of 21.4 mills/kWh is based on a first year fuel cost of \$3/MMBTU and a capacity factor of 0.91 . The calculated levelizing factor is $1.37^{3}$, an interest rate of $5.3 \%$, no inflation and a fuel escalation rate of $2.5 \%$ per year.

\section{COMPARISON WITHA 200 MW GAS TURBINE COMBINED CYCLE}

For perspective on the commercialization prospects for a $200 \mathrm{MW}$ plant with a hybrid power cycle, a comparison was made with a 200 MW gas turbine combined cycle. The comparison addressed issues of performance and cost of electricity. The gas turbine combined cycle selected for the comparison is a Siemens Kraftwerk Union GUD 1S84.3 rated at $227 \mathrm{MW}$. This system" has a single V84.3 gas turbine rated at $166 \mathrm{MW}$ and a $83 \mathrm{MW}$ steam turbine. The published heat rate is $6285 \mathrm{BTU} / \mathrm{kWh}$ LHV (54.3\% efficiency). Although manufacturers of larger combined cycle plants with more advanced tochnology are advertising efficiencies approaching $60 \%$, this model reflects presently available units for which comparison information is available.

The 30 year levelized cost of electricity for the $227 \mathrm{MW}$ combined cycle was estimated at 38.8 mills $/ \mathrm{kWh}$, without inflation, using EPRI TAG. The 30 year levelized plant cost is based on published cost of the $227 \mathrm{MW}$ combined cycle and estimates of installation and project cost. The O\&M cost is in 1995 dollars. The levelized fuel cost of 28.6 mills $/ \mathrm{kWh}$ is based on the same assumptions as used to estimate the fuel cost for the hybrid power cycle. A breakdown of cost of electricity is shown in Table 3 in comparison with the hybrid power cycle. Although the hybrid power cycle fuel cost at \$3/MMBTU is significantly less, the difference is not enough to offset higher plant and O\&M cost, which result in higher $\mathrm{COE}$ at this fuel cost.

TABLE 3.

\section{LEVELIZED COST OF ELECTRICITY COMPARISON} mills/kWh:

COE for Hybrid System is Greater Due Primarily to Higher Capital Cost

\begin{tabular}{|l|r|r|}
\hline & $\begin{array}{c}\text { HYBRID } \\
\text { POWER } \\
\text { CYCLE }\end{array}$ & $\begin{array}{c}\text { COMBINED } \\
\text { CYCLE }\end{array}$ \\
\hline FUEL & 21.4 & 28.6 \\
\hline PLANT & 12.5 & 4.8 \\
\hline O\&M & 11.9 & 5.4 \\
\hline TOTAL & 45.8 & 38.8 \\
\hline
\end{tabular}

The effect of first year fuel cost on the comparison is shown in Figure 5. The hybrid power cycle is competitive with the combined cycle for $200 \mathrm{MW}$ installations in which the first year fuel cost is above \$5.8/MMBTU.

The first year fuel cost at which the hybrid power cycle is competitive with the combined cycle is significantly influenced by fuel cell system cost. An increase in the fuel cell system cost from $1000 \$ / \mathrm{kW}$ to $1250 \mathrm{~S} / \mathrm{kW}$ increases the first year fuel cost at which the hybrid power cycle is competitive from 5.8 S/MMBTU to 7.5 S/MMBTU. A decrease in fuel cell system cost of $100 \$ \mathrm{~S} / \mathrm{KW}$ decreases the first year fuel cost at which the hybrid power cycle is competitive by 0.7 \$MMbTU. 




Notsian

FIGURE 5. COST OF ELECTRICITY:

Hybrid Cycle Will Be Competitive Above -6\$MMMBTU Fuel Cost

\section{MW HYBRID POWER CYCLE TECHNICAL CHALLENGES}

Hybrid power cycle commercialization for application in $200 \mathrm{MW}$ installations with high fuel cost requires that a number of technical challenges, identified below, be addressed.

Performance of the fuel cells under hybrid power cycle conditions must be verified. These conditions include the composition of gas to the anode which corresponds to the use of anode recycle as a means of providing water for the reforming process. In addition, relatively lean oxygen concentrations at the fuel cell cathodes were assumed which must be verified.

An anode recycle blower with a temperature capability of $650^{\circ} \mathrm{C}$ and seals that minimize fuel gas leakage under a pressure differential of about 3 psi must be found/developed.

The heat exchanger that transfers heat from the anode exit bumer to the compressed air from the gas turbine must be designed for a temperature of $1094^{\circ} \mathrm{C}$ and a design pressure of $400 \mathrm{psig}$. High temperature heat exchangers are presently under development by METC for application to coal gasification. A detailed understanding of this technology and its application to the hybrid power cycle is needed, particularly to meet the cost projections for this equipment.

The gas turbine in the hybrid power cycle has a relatively low power output. In addition, the compressor air is heated external to the gas turbine and then returned to the gas turbine burner for supplementary heating before passing through the turbine. Gas turbine technology must be reviewed in detail with suppliers and the design modified to accommodate the hybrid power cycle integration requirements.

\section{CONCLUSIONS}

A hybrid power cycle which includes direct carbonate fuel cells operating at near atmospheric pressure, a gas turbine and a steam system, is capable of generating power at a net LHV efficiency above $70 \%$. These results corroborate those published by DOE/METC 8
The performance is relatively insensitive to ambient temperature and site elevation. This new power cycle requires a high temperature heat exchanger to transfer heat from the fuel cell system to the gas turbine.

Studies of the hybrid power cycle for a $200 \mathrm{MW}$ plant, in which the system includes advanced heat exchanger technology indicate an efficiency of $70 \%$. Required heat exchanger development is a design that operates at $1094^{\circ} \mathrm{C}$ and 400 psia. The additional development of a fuel cell anode exit recycle compressor would result in a plant efficiency of $73 \%$. Emissions from the plant are expected to be well below existing or proposed standards. The $\mathrm{NO}_{x}$ emission level is $75 \%$ below the level from a combined cycle. A $200 \mathrm{MW}$ plant with a hybrid power cycle is competitive with a gas turbine combined cycle for installations where the fuel cost is above 55.8/MMBTU.

Technical challenges include verification of fuel cell performance at the system conditions chosen, development of a high temperature heat exchanger and an anode recycle blower. In addition, design integration of the cycle gas turbine is required.

\section{FURTHER STUDIES}

Studies of a near term high efficiency direct carbonate fuel cell/turbine hybrid power cycle have also been completed and are the subject of a paper to be presented at the Fuel Cell Seminar in Orlando, Florida in November 1996. These later studies were focused on a $20 \mathrm{MW}$ hybrid power cycle for near term application. A more moderate, $815^{\circ} \mathrm{C}$ heat exchanger, and with steam provided from the steam system rather than anode recycle were assimed. This hybrid power cycle has an estimated LHV efficiency of $65 \%$. The $\mathrm{NO}_{\mathrm{x}}$ emissions are $80 \%$ lower than a $20 \mathrm{MW}$ gas turbine combined cycle. The estimated cost of electricity for the near term $20 \mathrm{MW}$ plant with a hybrid power cycle is 50 mills/kWh, which is competitive with a $20 \mathrm{MW}$ combined cycle for installations where the fuel cost is above $\$ 2.5 / \mathrm{MMBTU}$.

\section{ACKNOWLEDGEMENT}

This study was conducted in cooperation with the U.S. DOE Morgantown Energy Technology Center under CRADA 93-014.

\section{REFERENCES}

1. CHEMCAD Version 3.0, Chemstations Inc., Houston, Texas.

2. EPRI-P-6571-L Technical Assessment Guide Vol. 1, Electrical Supply, Rev. 6, Sept. 1989.

3. EPRI-TR-100281 Technical Assessment Guide Vol. 3, Fundamental \& Methods - Electrical Supply, Rev. 6, December 1995.

4. Gas Turbine World Handbook, 1995 Edition.

5. Umberto Desideri, "Performance Analysis of Gas Turbines Operating at Different Atmospheric Conditions", Institute di Energetica di Perugia Italy, IGTI Vol. 9, ASME Cogen Turbo 1994.

6. Izumi Ushiyama, "Theoretically Estimating the Performance of Gas Turbines Under Varying Atmospheric Conditions", Ashigawa Institute for Technology, Japan, ASME Transactions Gas Turbine Conference, March 1975.

7. Communication with Paul Micheli, METC , June 1995.

8. Micheli, Paul L., "High Efficiency MCFC Bottomed Cycle", Fuel Cells '95 Review Meeting, U.S. DOE METC, Aug. 9-10, 1995. 